\title{
Leading higher education as and for the public good
}

\author{
Torgny Roxå \\ Lund University, Faculty of Engineering
}

Leading higher education as and for public good: Rekindling education as praxis. Edited by Tone Dyrdal Solbrekke \& Ciaran Sugrue, London, Routledge, 2019, I80 pp., £ 34.99 (paperback), ISBN 978-0367205126

Besides the editors, several other authors have contributed to this book: Andreas Bergh, Tomas Englund, Kristin Ewins, Trine Fossland, Ester Fremstad, Ragnhild Sandvoll, Molly Sutphen, and Johan Wickström. It is very much a product coloured by Scandinavia, even though Ciaran Sugrue is active in Dublin and Molly Sutphen pulls in experiences from North Carolina. The book is founded on the research project Formation and Competence Building of University Academic Developers (https://www.uv.uio.no/iped/english/research/projects/ solbrekke-formation-and-competence-building/).

This is definitely a book for those who believe that we ought to develop aspects of higher education that have been somewhat neglected over the last decades. There has been much talk about Bologna, about accountability and quality systems, and about employability. In contrast to these aspects, this book takes a stand for critical thinking and for the development of students as citizens; not only citizens of the university, but also of society. It is written by authors who argue for a turn towards a civil, yet critical style of conversation that scaffolds the development of new learning and personal growth. It serves as a call to higher education and the academic community to provide higher education as and for the public good that 'implies a social and moral responsibility broader than merely reporting on pre-determined, transparent and quantifiable quality criteria and learning outcomes.' (p. 166)

To my understanding, the authors argue that higher education is overwhelmed by ideas that an education can be seen as a private investment that can be evaluated by measuring its monetary pay-off, that a university career is a time period in which the number of publications forming one's private capital is expanded, and that a university's most prominent enterprise is to climb up the rankings, with a disregard of everything else. In these examples, knowledge and learning become a means to achieve a private goal in competition with others. Furthermore, this line of development encourages instrumental actions and protection of gains achieved, instead of generously making them public. The authors state that 'instrumental reason has gradually colonised the lifeworld of both universities as institutions and the actors within them.' (p. 38)

Instead, the authors favour higher education as a public good, open to anyone to join and contribute to. Public good is frequently contrasted with private good, according to the authors. A public good is 'something that is for the benefit of all, while private good, by comparison, is competed for, thus exclusive and manifestly, a commodity not available to all.' (p. 9) The threat is an increase in the privatisation of higher education and an instrumental accountability that cannot capture the full complexity of learning, research and personal growth. This forms

${ }^{*}$ Correspondence: torgny.roxa@genombrottet.lth.se

Artiklar och reflektioner är kollegialt granskade. Övriga bidragstyper granskas av redaktionen. Se https://hogreutbildning.se ISSN 2000-7558

(C)2020 Torgny Roxå. This is an Open Access article distributed under the terms of the Creative Commons Attribution-NonCommercial 4.0 International License (https://creativecommons.org/licenses/by-nc/4.0/), allowing third parties to share their work (copy, distribute, transmit) and to adapt it, under the condition that the authors are given credit, that the work is not used for commercial purposes, and that in the event of reuse or distribution, the terms of this license are made clear

Citation: Roxä, T. (2020). "Leading higher education as and for the public good", Högre utbildning, 10(2), 21-23. https://doi.org/10.23865/ hu.v10.2546 
the core question of this book: How do universities lead teaching and learning practices that encourage education as, and for, the public good?

For me as a reader, things like Liberal Education or Bildung come to mind: a Humboldtian university where the pursuit of knowledge forms the ethos of teaching and research. But here I must give the authors credit: the book is not sentimental at all. The authors do not strive for a rebirth of a golden era that is lost to us. Instead, they focus the book on the method they suggest can invigorate and strengthen the mission they support.

They want to rekindle higher education through strengthening the deliberative element in how we communicate. Deliberative communication implies an open and interested way of listening, but also a process where different views are confronted in a manner that is civil, permeated with respect. They also expand this into deliberative leadership, a distributed form of leadership that makes a stark contrast to managerialism or leaderism that has expanded. In academia, everyone is a leader and should take responsibility for the common good of higher education.

This is really the ethos of the book. We can change things for the better by treating higher education as a common good. It sounds like a version of the ethos of academia, the core of what it means to be an established academic or a becoming one; that is, to be a student. At this point, it is almost impossible to keep out images of fake news, internet trolls, Trumpism, or infotainment with people shouting at each other on the TV screen. Students (and academics) need to be challenged, to be pushed forward towards new insights about the world and themselves, but they need to be pushed in ways that are constructive, positive and caring. The game is not about manipulation, or the number of clicks or likes. An argument is not measured in terms of how many upset faces it produces, but how it can advance something we are all involved in and responsible for. Here, I admit, I am the one who is becoming sentimental, showing signs of being a hopeless romantic, deeply in love with my own idea of the university.

So, this is the way forward, via deliberative communication and deliberative leadership. But the authors do not stop at this. They appoint a group of academics of special importance to this endeavour. And this is where one might be a bit surprised. They claim that academic developers (or educational developers, or staff developers) are especially well-positioned to make a crucial contribution. The reason for this, they say, is that academic developers "are responsible for developing and leading the academic development programmes" (p. 54), that is, the mandatory pedagogical courses. But their expectations of academic developers do not stop there. They also say that 'institutional leaders increasingly expect academic developers to shape and influence how their university meets the increased and sometimes contradictory expectations' (p. 54), expectations formulated by an ever stronger and ever more diversified group of stakeholders.

Having been in academic development for over 30 years, I am not entirely convinced. There are limits to what can be done. Now, we academic developers are being asked to save the day, even though academic teachers and leaders often place very limited amounts of trust in what academic developers do. Frequent debates, for example in social media, illustrate this. Almost as frequently, reorganisations of teaching and learning centres bear similar witness. Do we really have the social, academic, or political capital for this?

Some of the authors appear to ask similar questions when the book dives into pedagogical courses, and study, in detail, how academic developers succeed in promoting deliberative communication. For an academic developer, or for any academic teacher, this is, in fact, the most interesting part of the book. In great detail, and with a lot of rigour, teaching is analysed. This is a study of teachers stuck in a web of commitments (as described by the authors), torn between 
professional integrity and a need to be accountable to stakeholders who are not present (and to those who are present). In short, it is a study of teachable moments that are missed, ambitions that are fulfilled only partly, and feelings of just not being able to reach that high standard of teaching the moment calls for (experiences shared by many ambitious teachers, and experiences that might have been forgotten by teachers who have settled for following a teaching recipe).

Those of the authors who courageously place themselves under the microscope for public scrutiny appear to have similar feelings of doubt. In one of the chapters, some of the authors who are also academic developers discuss their positions, status and credibility, and summarise thus: 'one of the greatest challenges for academic development work remains: to make a difference in practice.' (p. II7) In another chapter, similar issues are discussed and summarised: 'being an expert does not mean that academic developers tell people what to do; instead, being a professional academic developer seems to be about facilitating processes in which participants /.../ take ownership of the development and define what is important for them.' (p. 153-54) It is clearly hard for these academic developers to fully connect the wide ambition expressed within the book to a specific teaching session where many participants are invited, many views voiced, and many objectives reached. An experience, I believe, they share with many academic teachers or, for that matter, with teachers of all kinds.

I can only hope that the text above illustrates the power of this book: how intriguing it is and refreshing in its defence of values that academics often hold dear. It is also brave and inspiring in its in-depth studies of teaching and the lifeworld in which teachers as well as academic developers are embedded. The nuances and the complexity it tackles, together with a brilliant foreword by Ron Barnett, make it a really good and valuable book. 